\title{
Öğrencilerin Girişimcilik Eğilimi Üzerinde Aile Etkisinin Çok Yönlü Frekans Tabloları Analiziyle Belirlenmesi
}

\section{Determining the Effects of Students' Family Characteristics on Entrepreneurship Tendency by Multiway Frequency Analysis}

\section{Sema ULUTÜRK AKMAN ${ }^{1}$ (D)}

\section{ÖZ}

Girişimci, üretim faktörlerini bir araya getirerek üretim yapan ve dolayısıyla katma değer ve istihdam yaratan önemli bir ekonomik unsurdur. Bu sebeple girişimcilik, ekonomik büyüme ve kalkınma açısından da önemli bir araçtır. Girişimci ve girişimcilik kavramlarının ekonomi açısından önemi ve konuya duyulan ilginin artması, girişimciliği etkileyen faktörlerin neler olduğuna yönelik çalışmaları da arttırmıştır. Girişimciliğin, bireylerin kişilik özellikleri yanında doğup büyüdükleri aile ve demografik özelliklerden etkilendiği kabul edilmektedir. Bu çalışma, İstanbul Üniversitesi İktisat Fakültesi lisans programları öğrencilerinin girişimcilik niyetlerinin, öğrencilerin aile ve demografik özellikleriyle ilişkisini belirlemeyi amaçlamaktadır. Çalışma kapsamında 883 öğrenci ile görüşülerek aile özellikleri ve girişimcilik niyetleri sorulmuştur. Çok yönlü frekans analizi yöntemi kullanılarak veriler analiz edilmiş ve cinsiyetin, anne-babanın girişimci olmasının, ailenin gelir seviyesinin ve kaçıncı çocuk olarak dünyaya gelindiğinin girişimcilik eğilimi üzerinde etkili olduğu tespit edilmiştir. Buna göre, erkek öğrencilerde kendi işini kurma tercihi kadın öğrencilerden fazladır. Anne-babası girişimci olan öğrencilerde girişimcilik eğilimi daha yüksektir. Öte yandan yüksek gelirli aileye mensup öğrencilerin girişimci olma niyetinin ve ailenin ilk veya ikinci çocuğu olan öğrencilerde girişimcilik niyetinin daha fazla olduğu da tespit edilmiştir.

Anahtar kelimeler: Girişimcilik, Çok yönlü frekans analizi, Logaritmik doğrusal modeller

JEL Sınıflaması: L26, I23, C38

\section{ABSTRACT}

Entrepreneurs are vital economic actors that produce economic gains by combining the factors of production, hence creating added value and employment opportunities. Therefore, entrepreneurship is a fundamental tool for economic growth and development. The critical nature of the concepts of entrepreneurs and entrepreneurship to the economy and rising interest in this subject has resulted in a proliferation of

'Doç. Dr., İstanbul Üniversitesi, İktisat Fakültesi, Ekonometri Bölümü, İstanbul, Türkiye

ORCID: S.U.A. 0000-0002-4075-8313

Sorumlu yazar/Corresponding author: Sema ULUTÜRK AKMAN,

İstanbul Üniversitesi, İktisat Fakültesi, Ekonometri Bölümü, İstanbul, Türkiye

E-posta/E-mail: akmans@istanbul.edu.tr

Başvuru/Submitted: 14.04.2021

Revizyon Talebi/Revision Requested:

18.04.2021

Son Revizyon/Last Revision Received:

19.04.2021

Kabul/Accepted: 20.04 .2021

Atıf/Citation: Uluturk Akman, S. (2021).

Öğrencilerin girişimcilik eğilimi üzerinde aile etkisinin çok yönlü frekans tabloları analiziyle belirlenmesi. Istanbul iktisat Dergisi - Istanbul Journal of Economics, 71(1), 103-131. https://doi.org/10.26650/ISTJECON2021-915975 
studies on the factors affecting entrepreneurship. It is assumed that entrepreneurship is affected by demographic characteristics and family features as well as individuals' personality traits. The purpose of this study is to determine the association between the entrepreneurial intentions of undergraduate students of the University of Istanbul Faculty of Economics and traits and demographic characteristics of students' families. Within the scope of the study, 883 students were interviewed regarding the characteristics of their families and entrepreneurship intentions. The data were analyzed using the multiway frequency analysis method and indicated that gender, parents' tendencies toward entrepreneurship, family income level, and the number of siblings prior to or following the student's birth to be effective indicators of entrepreneurship tendencies. Accordingly, the findings imply that male students prefer starting their own business more than female students, and entrepreneurial tendencies are higher in students whose parents are entrepreneurs. In addition, students from highincome families indicated stronger entrepreneurship intentions and students who are the first or second children in a family signaled more entrepreneurial intentions.

Keywords: Entrepreneurship, Multiway frequency analysis, Loglinear models

JEL Classification: L26, 123, C38

\section{EXTENDED ABSTRACT}

Entrepreneurs are vital economic actors that produce economic gains by combining the factors of production, hence creating added value and employment opportunities. Therefore, entrepreneurship is a fundamental tool for economic growth and development. The concepts of entrepreneurs and entrepreneurship, which provide external economic benefit, have been extensively discussed in recent years.

Given the critical nature of this issue for the national economies, studies regarding the factors that contribute to the tendency for entrepreneurship have also gradually increased. In addition to the individuals' personality traits, entrepreneurship is thought to be affected by the demographic characteristics, and in this sense, the education level of the family, whether there is an entrepreneurial parent in the family, the person's age, gender, whether the individual is a first or second child, and the socioeconomic structure of the family are all considered to be factors that determine the tendency toward entrepreneurship. Living in rural or urban areas is another factor that has been demonstrated to have an effect on entrepreneurial tendencies.

This study, entitled 'Determining the Effects of Students' Family Characteristics on Entrepreneurship Tendency using Multiway Frequency Analysis," aims to determine the association between the family traits and demographic 
characteristics and the students' entrepreneurial intentions. To do so, data were collected through face-to-face interviews with 883 formal education students enrolled in the undergraduate diploma programs of the Faculty of Economics of the University of Istanbul using paper and pencil on a voluntary basis.

To determine the entrepreneurial tendency, the students were asked to favor the preferred option of paid employment or starting their own business following graduation to determine their entrepreneurial intentions. Surveys containing missing observations in terms of demographic characteristics and variables indicating family characteristics were eliminated, and a multiway frequency analysis was performed with 811 survey data.

Multiway frequency tables analysis is a method used to model cell frequencies, particularly in three or higher dimensional contingency tables. Multiway frequency tables analysis is a nonparametric analysis method developed to analyze the relationships between two or more variables measured on a nominal or ordinal scale, as well as the interactions between subcategories of variables. The method, also known as a loglinear model, is used in the analysis of categorical data and aims to estimate the observed frequency values for the levels of categorical variables and thus determine the effects of the levels of the variables on the observed frequencies.

Loglinear models, which create a special form of generalized linear models, are widely used in both social sciences and health sciences, as they offer a nonparametric method and do not require significant assumptions for applicability. Loglinear models used to model cell frequencies in contingency tables endeavor to estimate the parameters that define the relationships between categorical variables. An important feature of loglinear models is that they do not separate categorical variables into dependent and independent categories, and model cell frequencies for all combinations of levels of categorical variables in the model, evaluating all variables as independent. Therefore, loglinear models are used to determine how and to what extent the frequency in a particular cell of the contingency table depends on the levels of other categorical variables in the contingency table. 
Multiway frequency analysis is applied to hierarchically structured models. There are multiple models in question, starting from the most comprehensive saturated model to a full independence model in which all variables are unrelated. Therefore, it is necessary to determine the model that best estimates the observed frequencies in the contingency table and includes the fewest parameters as the best model. Although there are various algorithms for determining this best fit model, the commonly used method to determine the appropriate model is through a backward elimination method, which is based on removing nonsignificant interaction parameters from the model, starting with the saturated model. Alternative models were used to evaluate the data collected in the study, resulting in two models being determined as the best fit, which were then interpreted.

According to the suitable models determined as a result of the loglinear models, it was indicated that gender, parents being entrepreneurs, level of family income, and the number of children born prior to or following the stiudent's birth are effective indicators of entrepreneurship tendency. Accordingly, the findings imply that male students prefer starting their own business more than female students, and entrepreneurial tendencies are higher in students whose parents are entrepreneurs. In addition, students from high-income families indicated stronger entrepreneurial intentions. Furthermore, the findings imply that students who are the first or second born child have more entrepreneurial intentions than those born later. 


\section{Giriş}

Ürün ya da hizmet anlamında her türlü üretime, doğrudan ya da dolaylı katkı sağlayan tüm unsurlar, üretim faktörü olarak tanımlanmaktadır. Bu bağlamda üretim faktörlerinin neler olduğu ve kendi aralarında önem derecelerine göre nasıl sıralanacağı, üretim yanında zamanın şartlarına göre belirlenmektedir. Klasik iktisat teorisine göre, doğal kaynaklar, sermaye, emek ve girişimci (müteşebbis) üretim faktörlerini oluşturmaktadır. Geleneksel teoride üretim faktörlerinin hangi ülke gruplarında yoğun olduğuna bakıldığında, azgelişmiş ve gelişmekte olan ülkelerde emek ve doğal kaynakların; gelişmiş ülkelerde ise sermaye ve müteşebbisin daha yoğun olduğu görülmektedir. Öte yandan, klasik iktisat teorisinde yer alan dört temel üretim faktörünün tabii ve türetilmiş faktörler olarak ayrılması gerektiği de önerilmektedir. Buna göre, insan ve doğal kaynaklar tabii üretim faktörlerini, sermaye ve girişimci ise türetilmiş üretim faktörlerini oluşturmaktadır. Bu bağlamda insan ve doğal kaynaklar, doğanın bir parçası olarak değerlendirilirken, sermaye ve girişimci sonradan edinilmiş, kazanılmış varlık ve özellikler anlamında, türetilmiş üretim faktörleri olarak değerlendirilmektedir. (Karagül, 2013, s. 1-9).

Üretim faktörlerini bir araya getiren kişi olarak tanımlayabileceğimiz girişimci, kurduğu işletmenin faaliyetlerinden ve yönetiminden sorumlu olmakla beraber, işletmenin faaliyetleriyle ilgili riskleri de üstlenmektedir (Arslan, 2002, s. 3). Şüphesiz girişimci kavramı zaman içinde evrilmiş ve günümüz iktisadi dünyasında yeni özellikler kazanmış bir kavramdır. Yenilikçilik ve yaratıcılık da bu özellikler arasındadır ve bilgi toplumuna geçişle birlikte söz konusu kavramların gerek önemi gerekse bu kavramlara yapılan vurgu artmışır. Bu bağlamda girişimci, yeni fırsatları benimsemeye hevesli olma ve yaratıcı değişim için sorumluluk alma gibi tutumsal; fırsatları fark edebilme, değerlendirme, iş kavramını tanımlama, gerekli kaynakları belirleme, bu kaynakları sağlama, risk alarak uygulamaya geçme ve sonuçları kullanma gibi davranışsal özellikler taşır (Börü, 2006, s. 10).

Girişimcinin türetilmiş üretim faktörleri sınıfında yer alması, tabii üretim faktörü olan insanın bir takım özellik ve donanımlara sahip olması durumunda, türetilmiş 
üretim faktörü niteliğinde değerlendirilebileceğini gösterir. Bir diğer deyişle, tabii üretim faktörü olan insan, belirli özelliklere sahip olması durumunda türetilmiş üretim faktörüne dönüşmektedir.

Girişimcilerin sahip olması gereken özellikleri doğuştan gelen kişilik özellikler ve içinde yaşadığı sosyal, kültürel ve ekonomik çevrenin şekillendirdiği özellikler olarak iki gruba ayırabiliriz.

Girişimci olma kararının bireyin doğrudan kendisinin aldığı bir karar olması sebebiyle, bireylerin doğuştan getirdikleri kişilik özelliklerinin, girişimcilik niyet ve eğilimi üzerinde oldukça etkili olduğu düşünülmektedir (Littunen, 2000, s. 295296). Dolayısıyla girişimcilik kişilerin bireysel özelliklerine ve yeteneklerine bağlıdır. Bu bağlamda, girişimcilerin kişilik özelliklerine bakıldığında, başarma ihtiyacı, kontrol odağı, kendine güven, risk alma eğilimi, belirsizliğe karşı tolerans, bağımsızlık ve yenilikçilik gibi özelliklerin öne çıktığı görülmektedir (Korkmaz, 2012, s. 212-213).

Öte yandan bireyin yaş, cinsiyet, medeni durum, eğitim, ailede girişimci bulunması, ailenin ekonomik koşulları gibi demografik özelliklerinin de girişimcilik eğilimi üzerinde etkili olduğu kabul edilmektedir (Ballı ve Ballı, 2014, s. 103).

Girişimcilik olgusunu girişimcilerin bireysel özelliklerine odaklanarak açıklamaya çalışan bireysel yaklaşımda, işletme kuran ve kurdukları işletmede başarılı olan girişimcilerin özelliklerinin neler olduğu belirlenmeye çalışılır (Littunen, 2000, s. 296). Bu konuyla ilgili olarak büyük ölçüde, kişilerin demografik özellikleri ve kişilik özellikleri ön plana çıkmakta, girişimcilik vasıflarının kaynağı olarak bireylerle ilgili özellikle psikolojik ve sosyolojik etkiler üzerinde durulmaktadır. Buna göre, girişimciler psikolojik açıdan risk almaya, yüksek başarı elde etmeye ve içsel kontrol odaklı olmaya eğilimli kişilerdir (Durak, 2011, s. 197). Öte yandan girişimcilerin, toplumsal statü kazanma isteği, kararlılık, yaratıcılık, yenilikçilik gibi kişilik özellikleri yanında belirsizlikleri fırsata dönüştürme, fırsatlardan yararlanma, sınırlı kaynakları koordine etme ve etkili kullanma, kendini gerçekleştirme, sorumluluk ve inisiyatif alabilme, değişimlere ayak uydurabilme ve sürdürülebilir 
sağlıklı ilişkiler kurma becerilerine de sahip oldukları kabul edilmektedir (ibicioğlu, Özdaşlı ve Alparslan, 2009, s. 522).

Bireysel yaklaşımda ayrıca, bireyin demografik özelliklerinin de girişimcilik eğilimi üzerinde etkili olduğu düşünülmekte ve bu anlamda ailenin eğitim düzeyi, ailede girişimci ebeveyn bulunup bulunmadığı, kişinin yaşı, cinsiyeti, ilk çocuk olup olmadığı ve ailenin sosyoekonomik yapısı girişimcilik eğilimini belirleyen faktörler olarak değerlendirilmektedir. Ayrıca, ailenin ve bireyin kırsal ya da kentsel alanda yaşıyor olması da girişimcilik eğilimi üzerinde etkili bir diğer faktördür (Kök, 2007, s. 42, 58).

Çevresel yaklaşımda ise, bireysel yaklaşımın girişimcilik üzerinde önemli rolü olduğu kabul edilmekle beraber, çevre de, bireylerin girişimcilik eğilimleri üzerindeki etkili bir faktör olarak değerlendirilmektedir (Durak, 2011, s. 198).

Çevresel yaklaşıma göre, bireyin içinde yaşadığı dar ve geniş anlamda çevre ve çevre koşulları girişimcilik eğilimini belirlemektedir. Bu bağlamda çevre koşulları aile, kültür, finansal kaynaklar ve hükümet politikaları gibi pek çok faktör doğrudan ya da dolaylı olarak bireylerin girişimcilik eğilimlerini etkilemektedir. Dolayısıyla, aile, toplum, sosyal, kültürel ve ekonomik koşullar yanında en geniş anlamda devlet ve hükümet politikaları da bireyin girişimcilik eğilimi üzerinde çeşitli imkânlar ve/ veya zorluklar yaratabilmektedir.

Öte yandan, ülkelerin ekonomik, toplumsal ve kültürel altyapıları da girişimcilik olgusu üzerinde etkili olmaktadır. Örneğin ülkelerin dışa açıklığı, devletin ekonomideki rolü, finans sektörünün etkinliği, teknoloji yoğunluğu, yönetim becerileri, esnek işgücü pazarı, yasal kurumlar, ekonomik büyüme, ekonominin dışa açıklığı, sosyal, politik, kültürel ortam ve fiziki altyapı ve ekonomik altyapı yanında; finans ve devlet politikaları, devlet programları, Ar-Ge transfer, ticari altyapı ve kültürel normlar gibi girişimcilik altyapısı da, ülkelerin girişimcilik altyapısını oluşturan unsurlar arasında sıralanabilir (Börü, 2006, s. 19).

Girişimcilik sadece yeni bir işletme kurmakla sınırlı kalmayıp, kurulan işletmenin devamlılı̆ını sağlamayı da kapsar. Dolayısıyla, işletmeyi idari ve finansal açıdan 
yönetebilme becerisi de son derece önemlidir. Bu noktada firma yaklaşımı ise, girişimcinin yöneticilik boyutu üzerine odaklanmakta ve girişimcinin işletmenin kuruluşundan sonra büyüme, olgunluk ve istikrar aşamalarında da başarılı yönetici özelliği gösterebilmesini ifade etmektedir (Kaygın ve Güven, 2015, s. 21).

Sosyal bir varlık olan insanın girişimcilik eğilimi üzerinde pek çok faktörün etkili olduğu ve bu faktörlerin bireysel, çevresel ve firma olmak üzere üç yaklaşımla değerlendirildiği görülmektedir.

Bireylerin girişimcilik eğilimleri üzerinde etkili olan faktörlere yönelik araştırmalarda, firma yaklaşımının daha ziyade girişimci vasfını kazanmış kişilerin işletmedeki başarısına odaklanması sebebiyle, bireysel ve çevresel yaklaşımlar özellikle önem taşımaktadır.

Bireysel ve çevresel yaklaşımların her ikisinin de kapsamı içinde yer alan demografik özellikler ve aile faktörü, girişimcilik eğilimi üzerinde iki boyutta etki yaratması sebebiyle özellikle dikkat çekmektedir. Ailenin, insanın içine doğduğu en küçük sosyal yapı olduğu düşünüldügünde, aile yapısı ve demografik özellikler genel anlamda bir bireyin doğduğu ve büyüdüğü koşulları, diğer deyişle çocukluk ve gençlik dönemlerini geçirdiği koşulları ifade etmekte ve aile faktörü olarak nitelendirilmektedir.

Aile faktörü adı altında sıralanabilecek anne-babanın kişilik özellikleri, meslekleri, ailenin sosyoekonomik ve sosyokültürel yapısı, ebeveynin ve ailenin diğer fertlerinin eğitim durumları, ailenin kırsal alanda ya da kentte yaşıyor olması, ailenin sosyal çevresi vb. pek çok özellik bireyin girişimcilik istek ve eğilimi üzerinde etkili olmaktadır.

Dolayısıyla, ailenin sosyal, kültürel ve ekonomik yaşam koşulları, aileye eklenen küçük bireyin gelişiminde son derece etkili olacaktır. Yukarıda bireysel yaklaşımla ilgili olarak sayılan pek çok faktör doğrudan aile ile ilgilidir. Örneğin, bireyin ekonomik durumu, eğitim imkânı, kentsel ya da kırsal bölgede yaşıyor olması, ailede girişimci bulunup bulunmaması, aileden maddi ve manevi anlamda destek görüp görememesi, anne-baba başta olmak üzere aile üyelerinin eğitim düzeyleri, 
sosyokültürel ve sosyoekonomik seviyeleri gibi pek çok faktör, aile ile doğrudan ya da dolaylı ilgili faktörlerdir. Öte yandan aile, sayılan unsurlar itibarıla girişimcilik eğilimine bireysel anlamda etki ederken, aynı zamanda çevresel anlamda da etki etmektedir. Ailenin sahip olduğu imkânlar, ailenin sosyal ve kültürel çevresini oluşturacağından, söz konusu çevrenin özellikleri, tüm aile fertleri üzerinde olumlu ya da olumsuz etkiler yaratacaktır. Bu açıdan aile faktörü, bireylerin hem bireysel hem çevresel anlamda girişimcilik eğilimini belirleyen unsurlardan biri olmaktadır.

Sonuç olarak, girişimcilik teorisi, cinsiyet gibi doğuştan sahip olunan özellikler yanında bireyin içinde doğup büyüdüğü ailenin çeşitli özelliklerinin girişimcilik eğilimi üzerinde etkili olduğuna işaret etmektedir. Bu çalışma ile de, öğrencilerin cinsiyeti, kaçıncı çocuk olarak dünyaya geldiği, ailenin gelir seviyesi, anne ya da babadan en az birinin girişimci olması ve girişimcilik eğilimi bir arada değerlendirilecek ve çok yönlü frekans analiziyle söz konusu değişkenler arasındaki etkileşimler belirlenmeye çalışılacaktır. Bu amaçla, önce bu konuda yapılmış araşıırmalara yönelik literatür özetlenecek ardından araştırmanın metodolojisi kapsamında veri toplama süreci, çalışmanın analiz yöntemi olan çok yönlü frekans analizine değinilecek ve elde edilen bulgular değerlendirilecektir.

\section{Literatür Özeti}

Bireyin demografik ve aile ile ilgili özelliklerinin girişimcilik eğilimi üzerinde etkisini belirlemeyi amaçlayan çok sayıda çalışma yapılmıştır. Bu çalışmalardan bazılarını şu şekilde sıralayabiliriz:

Kök (2007), "Küçük ve Orta Ölçekli İşletmeler ve Kadın Girişimciliğii" isimli araştırmasında, ailenin ilk çocuğu olmanın, ailenin eğitim seviyesinin yüksek olmasının ve ailede girişimci varlığının girişimcilik eğilimini arttırdığını tespit etmiştir.

Arslan (2002), "Üniversiteli Gençlerde Mesleki Tercihler ve Girişimcilik Eğilimleri" isimli çalışmasında, ebeveynin eğitim durumunun, gelir seviyesinin ve ailedeki çocuk sayısının girişimcilik eğilimi üzerinde etkili olduğunu ifade etmektedir. 
Duygulu (2008), "Algılanan Kurumsal Görünüm, Proaktif Kişilik Özelliği ve İş Kurma (Girişimcilik) Tutumu: Dokuz Eylül Üniversitesi Sosyal Bilimler Enstitüsü Öğrencileri Üzerine Bir İnceleme" isimli araştırmasında ailede kendi işini yapan bir aile üyesi bulunmasıyla bireyin girişimci eğilimi arasında bir ilişki bulunduğunu ortaya koymuştur.

Kalkan (2011), "Kişisel Tutum, Öznel Norm ve Algılanan Davranış Kontrolünün Girişimcilik Niyeti Üzerindeki Etkisi: Üniversite Öğrencileri Üzerine Bir Uygulama" isimli çalışmasında ailenin ilk çocuğu olmayla girişimcilik eğilimi arasında bir ilişki bulunduğunu, ailenin girişimci yapısının çocuğun girişimci eğilimi üzerinde etkili olduğunu ifade etmektedir.

İrmiş ve Barutçu (2012), "Öğrencilerin Kendilerini Girişimci Bir Kişiliğe Sahip Görmelerini ve Iş̧ Kurma Niyetlerini Etkileyen Faktörler: Bir Alan Araştırması" isimli çalışmalarında, kendi işini kurmuş, girişimci bir babaya sahip olma ve ailede girişimci bulunmasıyla bireyin girişimcilik eğilimi arasında ilişki bulunduğunu belirlemiştir.

Çelik, İnce ve Bozyiğit (2014), "Üniversite Öğrencilerinin Girişimcilik Niyetlerini Etkileyen Ailesel Faktörleri Belirlemeye Yönelik Bir Çalışma" isimli araştırmasında, ailesinde ya da yakın çevresinde girişimci olma ile girişimcilik eğilimi arasında ilişki olduğunu, anne-babanın eğitimi ve kaçıncı çocuk olarak dünyaya gelindiğinin ise girişimcilik eğilimini etkilemediğini tespit etmiştir.

İbicioğlu ve ark. (2009), "Girişimci Özellikler ve Girişimcilik Türü Tercihi Üzerinde Ebeveyn Etkisi: Mehmet Akif Ersoy Üniversitesi Araştırması" isimli çalışmasında, anne ve babaların başarılı girişimciler olmasının çocuklarının girişimci özelliklerini arttırdığını ve girişimcilik türü tercihlerini etkilediğini; başarılı girişimci olan ebeveynlerin çocuklarının başarısız girişimcilik deneyimi yaşayan ebeveyn çocuklarına kıyasla daha fazla risk alma eğiliminde olduklarını ve aynı zamanda kaynakların etkin kullanımına da dikkat ettiklerini tespit etmiştir. Çalışmada ayrıca anne ve babanın eğitim seviyesinin ve kırsal ya da kentsel kesimde yaşıyor olmasının da çocukların girişimcilik eğilimi ve girişimcilik türü üzerinde etkili olduğu da belirlenmiştir. 
Şeşen ve Basım (2012), "Demografik Faktörler ve Kişiliğin Girişimcilik Niyetine Etkisi: Spor Bilimleri Alanında Eğitim Gören Üniversite Öğrencileri Üzerine Bir Araştırma" isimli çalışmalarında, erkek öğrencilerin girişimcilik niyetlerinin kız öğrencilere göre yüksek olduğunu, ayrıca, yüksek gelir seviyesine sahip ailelerin çocuklarının düşük gelirli ailelere kıyasla girişimcilik eğilimlerinin daha yüksek olduğunu tespit etmiştir.

Korkmaz (2012), "Üniversite Öğrencilerinin Girişimcilik Eğilimlerini Belirlemeye Yönelik Bir Araştırma: Bülent Ecevit Üniversitesi Örneği" çalışmasında, ailesinde girişimci olan öğrencilerin girişimcilik eğiliminin, ailesinde girişimci olmayan öğrencilere kıyasla yüksek olduğunu, çocukların aile büyüklerini rol model almalarının bu konuda etkili olduğunu belirlemiştir.

Örücü, Kılıç ve Yılmaz (2007), "Üniversite Öğrencilerinin Girişimcilik Eğilimlerinde Ailesel Faktörlerin Etkisi Üzerine Bir Uygulama" isimli çalışmalarında, gelir düzeyi yüksek aile çocuklarının diğer gelir düzeylerine kıyasla girişimcilik eğitiminin yüksek olduğunu; öğrencilerin cinsiyetinin ve ailede girişimci bulunmasının ise girişimcilik eğilimini etkilemediğini tespit etmiştir.

Girişimcilik eğilimi üzerinde aile etkisini ortaya koymak üzere çok sayıda çalışma gerçekleştirildiği görülmektedir. Söz konusu çalışmalar çeşitli üniversitelerin, fakülte, yüksekokul ve enstitülerinde, önlisans, lisans ve lisansüstü düzeyde öğrencilerle gerçekleştirilmiştir. Bu çalışmada ise İktisat Fakültesi öğrencilerinin girişimcilik eğilimi üzerinde aile faktörünün etkisi belirlenmeye çalışılacaktır. Bu bağlamda, ailenin gelir seviyesi, anne-babanın girişimci olup olmaması, öğrencinin cinsiyeti ve kaçıncı çocuk olduğu, girişimcilik eğilimiyle birlikte değerlendirilecek ve değişkenler arasındaki etkileşimler bu alanda daha önce kullanılmamış bir yöntem olan çok yönlü kontenjans analizi ile ortaya koyulmaya çalışılacaktır.

\section{Metodoloji ve Bulgular}

Bu çalışmada üniversite öğrencilerinin girişimcilik eğilimi üzerinde aile faktörünün etkisi ortaya konulmaya çalışılmıştır. Bu amaç doğrultusunda çalışmanın 
anakütlesi, İstanbul Üniversitesi İktisat Fakültesi'nde örgün eğitim programlarına kayıtlı yaklaşık 7000 öğrenci olarak belirlenmiştir. Bu kitleyi temsil etmek üzere İstanbul Üniversitesi İktisat Fakültesi'nde kayıtlı 883 öğrenciden yüz yüze anket yöntemiyle veri toplanmıştır.

\subsection{Anket Tasarımı ve Örneklem}

Bu çalışmanın verisi, üniversite öğrencilerinin girişimcilik ile ilgili niyet ve tutumlarını ortaya koymak amacıyla demografik ve yargısal sorulardan oluşan bir anket formu ile toplanmıştır. Anket formunu hazırlamaya yönelik literatürde yer alan pek çok çalışma incelenmiş ve özellikle üniversite öğrencilerinin girişimcilik profilini tanımlamak üzere Mueller ve Anisya (2000, s. 51-75), Teoh ve Foo (1997, s. 67-81), Lee, Lim, Pathak, Chang ve Li (2011, s. 1-15), Türker ve Senem'in (2009, s. 142-159) çalışmalarından yararlanılmıştır. Sözü edilen çalışmalardan hareketle, girişimcilere ilişkin özelliklerden kontrol odağı, risk alma eğilimi, belirsizliğe karşı tolerans, yenilikçi olma, kendine güven ve algılanan eğitim desteği olmak üzere toplam altı boyutu dikkate alan bir anket formu oluşturulmuş ve yararlanılan ölçeklerden seçilen sorular Türkçe'ye uyarlanarak pilot çalışma gerçekleştirilmiştir.

Pilot uygulama neticesinde ölçek, altı boyuttan meydana gelen 5 düzeyli likert ölçeği halini almış ve ölçekteki algı ifadelerine yönelik yanıt seçenekleri: hiç katılmıyorum-1, katılmıyorum-2, kararsızım-3, katılıyorum-4, kesinlikle katılıyorum-5 şeklinde düzenlenmiştir. Ayrıca, katılımcılara aile ve demografik özelliklerine yönelik sorular da yöneltilmiştir. Yargısal sorulara yönelik değerlendirme bir başka çalışma kapsamında tamamlanmış ve yayınlanmışıı (Akman ve Bektaş, 2015, s. 217-232).

Bu çalışma ile de iktisadi büyüme ve kalkınma açısından son derece önemli olan girişimcilik eğilimi, üniversite öğrencileri açısından incelenmiş ve bu amaçla İstanbul Üniversitesi İktisat Fakültesi örgün eğitim programlarına kayıtlı 883 öğrenci ile görüşülmüştür. Öğrencilerin gönüllülük esasına göre katıldığı anket çalışması, kağıt-kalem kullanılarak yüz yüze gerçekleştirilmiştir. 
Ankete katılan 883 öğrencinin, \%46'sı erkek, \%54'ü kadındır ve katılımcıların $\% 34,8$ 'inin ebeveynlerinden en az biri girişimcidir. Öte yandan ankete katılan öğrencilerin yaklaşı \%60' I İstanbul'da ailesiyle birlikte ikamet etmektedir ve \%85'i 18-24 yaş grubundadır. Ayrıca katılımcıların \%5'i ailesinin gelir seviyesini düşük olarak nitelemekte, \%83'ü orta ve \%12 'si ise yüksek gelir seviyesinde olduğunu düşünmektedir.

Çalışmanın analiz yöntemi olan çoklu frekans analizini uygulayabilmek açısından, demografik sorulara ilişkin boş yanıtların bulunduğu anket formları elenmiş ve 811 ankete ilişkin veriler analizde kullanılmıştır.

\subsection{Yöntem}

Çalışmada, özellikle üç ya da daha yüksek boyutlu kontenjans tablolarında hücre frekanslarını modellemek amacıyla kullanılan çok yönlü frekans analizi yöntemi kullanılmıştır. Çok yönlü frekans analizi, nominal ya da ordinal ölçüm düzeyinde iki veya daha çok değişken arasındaki ilişkileri ve bunun yanında değişkenlerin alt kategorileri arasındaki etkileşimleri analiz etmek üzere geliştirilmiş parametrik olmayan bir analiz yöntemidir. Logaritmik doğrusal modeller olarak da bilinen yöntem, kategorik verilerin analizinde kullanılmakta olup, kategorik değişkenlerinin düzeyleri için gözlenen frekans değerlerini tahmin etmeyi ve dolayısıyla değişkenlerin düzeylerinin gözlenen frekanslar üzerindeki etkilerini belirlemeyi amaçlar.

Genelleştirilmiş doğrusal modellerin özel bir formunu oluşturan logaritmik doğrusal modellerin, parametrik olmayan bir yöntem olması ve uygulanabilirliği için önemli varsayımlar gerektirmemesi sebebiyle söz konusu modeller, gerek sosyal bilimler gerekse sağlık bilimleri alanında yaygın olarak kullanılmaktadır.

Kontenjans tablolarında yer alan hücre frekanslarını modellemek için kullanılan logaritmik doğrusal modeller, kategorik değişkenler arasındaki ilişkiyi tanımlayacak parametreleri tahmin etmeyi amaçlar. Logaritmik doğrusal modellerin önemli bir özelliği, kategorik değişkenleri bağımlı-bağımsız değişken olarak ayırmaması ve 
modelde yer alan kategorik değişkenlerin düzeylerinin tüm kombinasyonları için hücre frekanslarını modelleyerek, tüm değişkenleri bir bağımsız değişken gibi değerlendirmesidir. Dolayısıyla logaritmik doğrusal modeller, kontenjans tablosunun belirli bir hücresindeki frekansın kontenjans tablosunda yer alan diğer kategorik değişkenlerin düzeylerine nasıl ve ne ölçüde bağlı olduğunu belirlemek amacıyla kullanılmaktadır. Diğer bir deyişle her kategorik değişken model içinde, hücre frekanslarını belirleyen bir bağımsı değişken gibi ele alınmaktadır. (Azen ve Walker, 2011, s. 137).

Çok yönlü frekans analizi yöntemi, kontenjans tablosunda yer alan hücre frekanslarını bir bağımlı değişken gibi ele alıp tüm kategorik değişkenleri birer bağımsız değişken gibi kullanarak en çok benzerlik yöntemine göre tahmin eder. Örneğin, X, Y ve Z şeklinde isimlendirilen üç kategorik değişken söz konusu olduğunda, değişkenlerin $\mathrm{i}, \mathrm{j}, \mathrm{k}$ hücresindeki beklenen frekansı $\mu_{i j k_{\text {I }}}$

$$
\left(\mu_{i j k}\right)=\lambda+\lambda_{i}^{X}+\lambda_{j}^{Y}+\lambda_{k}^{Z}+\lambda_{i j}^{X Y}+\lambda_{i k}^{X Z}+\lambda_{j k}^{Y Z}+\lambda_{i j k}^{X Y Z}
$$

modeli ile tahmin edilecek ve bu model $X, Y$ ve $Z$ değişkenlerinin sırasıyla I, J ve K adet düzeylerinin her bir kombinasyonu için oluşturulacak bir model olacak ve doygun model olarak adlandırılacaktır.

Modelde yer alan,

$\lambda$, ortalama etkiyi,

$\lambda_{i}^{X}, \lambda_{j}^{Y}$ ve $\lambda_{k}^{Z}, \mathrm{X}, \mathrm{Y}$ ve $\mathrm{Z}$ değişkenlerinin ana etkilerini,

$\lambda_{i j}^{X Y}, \lambda_{i k}^{X Z}$ ve $\lambda_{j k}^{Y Z}$, değişkenler arasındaki ikili etkileşim etkilerini (yani $\lambda_{i j}^{X Y}$, $\mathrm{X}$ ile $Y$ değişkeni arasındaki etkileşim etkisini, $\lambda_{i k}^{X Z} X$ ve $Z$ değiş̧enleri arasındaki etkileşim etkisini ve $\lambda_{j k}^{Y Z}$ ise $Y$ ve $Z$ değişkeni arasındaki etkileşim etkisini),

$\lambda_{i j k}^{X Y Z}$ ise $\mathrm{X}, \mathrm{Y}$ ve $Z$ değişkenleri arasındaki üçlü etkileşim etkisini göstermektedir (Topaloğlu ve Atay, 2020, s. 568). 
Modelde yer alan $\lambda_{i j k}^{X Y Z}$, üç yönlü etkileşim terimi, herhangi iki değişken arasındaki odds oranının üçüncü değişkenin kategorisine ya da düzeyine göre değişebileceğini göstermektedir. Dolayısıyla, herhangi iki değişken arasındaki odds oranının, üçüncü değiş̧kenin tabakalarına bağlı olma biçiminin modellenmesi, üç yönlü etkileşim teriminin modelde yer almasıyla sağlanabilmektedir. Başka bir deyişle üç yönlü etkileşim teriminin modelde bulunmaması, herhangi iki değişken arasındaki odds oranını üçüncü değişkenin tüm tabakaları için eşit olacak şekilde sınırlamaktadır (Azen ve Walker, 2011, s. 144). Dolayısıyla, üçlü etkileşim teriminin modelde yer almaması üçüncü değişkenin kategorilerine göre diğer iki değişken arasındaki odds oranının değişmediği anlamına gelmektedir.

Herhangi iki değişken arasındaki ilişkinin, üçüncü değişkenin düzey ya da tabakaları arasında farklılık göstermediğini söylemek, üç değişken arasında etkileşim olmadığını ve dolayısıyla üçlü etkileşim teriminin logaritmik doğrusal modelde yer almaması gerektiği sonucunu doğurmakta ve bu durumda model,

$$
\log \left(\mu_{i j k}\right)=\lambda+\lambda_{i}^{X}+\lambda_{j}^{Y}+\lambda_{k}^{Z}+\lambda_{i j}^{X Y}+\lambda_{i k}^{X Z}+\lambda_{j k}^{Y Z}
$$

biçiminde kurulmakta ve homojen ilişki modeli olarak adlandırılmaktadır. (Agresti, 2007, s. 208-209).

Değişkenlerin kendi aralarında ilişki ya da etkileşim içinde olmadıkları ya da başka bir deyişle, her bir değişkenin diğer tüm değişkenlerden bağımsız olması durumunda ise,

$$
\log \left(\mu_{i j k}\right)=\lambda+\lambda_{i}^{X}+\lambda_{j}^{Y}+\lambda_{k}^{Z}
$$

modeli söz konusu olmakta ve bu model değişkenlerin yalnızca ana etkilerini içeren tam bağımsızlık modeli olarak adlandırılmaktadır (Azen ve Walker, 2011, s. 154).

Oysa değişkenlerin bir kısmı ilişkili ya da bir kısmı bağımsız da olabilir. Örneğin,

$$
\log \left(\mu_{i j k}\right)=\lambda+\lambda_{i}^{X}+\lambda_{j}^{Y}+\lambda_{k}^{Z}+\lambda_{i k}^{X Z}+\lambda_{j k}^{Y Z}
$$


modeli koşullu bağımsızlık modelidir. Modelde yer alan $\lambda_{i k}^{X Z}$ parametresi $Y$ değişkeni sabitken ya da kontrol altındayken $X$ ve $Z$ değişkenleri arasındaki ilişkiyi göstermektedir. Benzer şekilde, modelde yer alan $\lambda_{j k}^{Y Z}$ parametresi ise $\mathrm{X}$ değişkeni kontrol altındayken $\mathrm{Y}$ ve $\mathrm{Z}$ değişkenleri arasındaki ilişkiyi ifade etmektedir.

Modelde, $Z$ değişkeni kontrol altındayken $X$ ve $Y$ değişkenleri arasındaki etkileşimi gösteren $\lambda_{i j}^{X Y}$ parametresi yer almamaktadır. Bunun sebebi, $Z$ değişkeni sabitken $X$ ve $Y$ değişkenlerinin koşullu bağımsız olmalarıdır. Işste üçüncü değişkenin kontrol altında olması durumunda diğer iki değişken arasındaki koşullu ilişkiyi gösteren ve aynı zamanda üçüncü değişken sabit olduğunda diğer iki değişken arasındaki koşullu bağımsızlığı temsil eden bu tür modellere koşullu bağımsızlık ya da koşullu ilişki modelleri denmektedir (Agresti, 2007, s. 208).

$X, Y$ ve $Z$ şeklinde gösterilen üç değişkenden ikisinin bağımsız olması durumunda ise ortaya çıkan model kısmi bağımsızlık modeli ya da ortak olasılık modeli olarak adlandırılmaktadır. Örneğin, $X$ ile $Z$ ve $Y$ ile $Z$ değişkenlerinin bağımsız olmaları durumunda değişkenlerin ana etkilerini ve $X$ ve $Y$ değişkeni arasındaki etkileşim etkisini içeren model,

$$
\log \left(\mu_{i j k}\right)=\lambda+\lambda_{i}^{X}+\lambda_{j}^{Y}+\lambda_{k}^{Z}+\lambda_{i j}^{X Y}
$$

biçiminde kurulacaktır. Söz konusu modelde $X$ ile $Z$ ve $Y$ ile $Z$ değişkenlerinin bağımsız olmaları sebebiyle aralarında ilişki ya da etkileşim bulunmayacak ve bu değişkenler arasındaki etkileşimi ifade eden $\lambda_{i k}^{X Z}$ ve $\lambda_{j k}^{Y Z}$ parametrelerin değerleri sıfır olacağından söz konusu parametreler modelde yer almayacaklardır (Azen ve Walker, 2011, s. 153).

Çok yönlü frekans analizi, yukarıdaki modellerden de anlaşılacağı gibi hiyerarşik yapıda modellerden oluşur. Dolayısıyla, söz konusu modeller arasında kontenjans tablosundaki gözlenen frekansları en iyi tahmin eden ve parsimony ilkesi gereği en az parametre içeren model en iyi model olarak seçilir. En uygun modelin seçimine yönelik farklı algoritmalar söz konusu olmakla beraber en çok kullanılan yöntem, doymuş modelden başlayarak, anlamlı olmayan etkileşim parametrelerini 
modelden çıkarmak esasına dayanan geriye doğru eleme yöntemiyle uygun modeli belirlemektir (Saraçbaşı ve Altunay, 2016, s. 71).

Uygun model ile ilgili olarak gözlenen ve model ile tahmin edilen frekansların ne derece uyumlu olduğu Ki-kare uygunluk testi ve/veya olabilirlik oran testi ile sınanmakta (Azen ve Walker, 2011, s.153), aynı zamanda gözlenen frekanslar ile beklenen frekanslar arasındaki farklar üzerinden hesaplanan standartlaştııılmış kalıntıların mutlak değer olarak 2 değerini aşmaması istenmektedir (Agresti, 2007, s. 38).

Modellerin hiyerarşik yapısı sebebiyle, üst düzey etkileşim teriminin modelde yer alması durumunda düşük düzeyli etkileşim terimlerinin de modelde yer alması gerekecektir (Altaş ve Yıldııım, 2003, s. 217).

Çoklu frekans analizinde, uygun model olarak belirlenen modelde yer alan ana etki parametreleri, ilgili değişkene yönelik odds değerinin logaritmasını; ikili etkileşim parametreleri ise ilgili iki değişkene ilişkin odds oranının logaritmasını vermektedir. Böylelikle, modelde yer alan parametre tahminlerinin doğrudan üstel değerlerini hesaplayarak odds değerine ve odds oranına ulaşılabilmektedir (Azen ve Walker, 2011, s. 161-162).

\section{Bulgular}

Girişimci ve girişimcilik konularında yapılan gerek teorik gerekse uygulamalı çalışmalar, bireylerin girişimcilik eğilimleri üzerinde demografik faktörlerin ve aile özelliklerinin etkili olduğunu göstermektedir. Buna göre, bireyin cinsiyeti, kaçıncı çocuk olduğu, anne ya da babasının girişimci olup olmadığı, ailesinin gelir düzeyi vb. özellikleri girişimcilik eğilimi üzerinde etkili değişkenler olarak kabul edilmektedir.

Çoklu frekans analizine yönelik kurulan ilk model, öğrencilerin cinsiyeti (K1), kaçıncı çocuk olduğu (YK3), anne-babanın girişimci olup olmadığı (K5) ve öğrencinin mezun olduktan sonra girişimci olmayı düşünüp düşünmediğini gösteren (K12) değişkenler ile oluşturulmuştur. Söz konusu modele yönelik değişkenler arasındaki tüm etkileşimler Tablo 1'de verilmiştir: 
Tablo 1: Değişkenlerin Etkileşim Etkileri

\begin{tabular}{|l|l|c|c|c|c|c|c|}
\hline \multicolumn{2}{|c|}{} & \multicolumn{6}{|c|}{ K-Yönlü ve Yüksek Dereceli Etkiler } \\
\cline { 3 - 8 } & $\mathbf{K}$ & $\begin{array}{c}\text { Serbestlik } \\
\text { derecesi }\end{array}$ & Ki-kare & $\begin{array}{c}\text { Anlamlılık } \\
\text { seviyesi }\end{array}$ & Ki-kare & $\begin{array}{c}\text { Anlamlılık } \\
\text { seviyesi }\end{array}$ & $\begin{array}{c}\text { İterasyon } \\
\text { Sayısı }\end{array}$ \\
\hline \multirow{3}{*}{$\begin{array}{l}\text { K-yönlü ve } \\
\text { Yüksek Dereceli } \\
\text { Etkiler }\end{array}$} & 1 & 31 & 610,774 & 0,000 & 741,612 & 0,000 & 0 \\
\cline { 2 - 8 } & 2 & 25 & 107,714 & 0,000 & 119,338 & 0,000 & 2 \\
\cline { 2 - 8 } & 3 & 13 & 13,982 & 0,375 & 13,880 & 0,382 & 4 \\
\cline { 2 - 8 } & 4 & 3 & 4,129 & 0,248 & 4,119 & 0,249 & 3 \\
\hline \multirow{3}{*}{ K-yönlü Etkiler } & 1 & 6 & 503,060 & 0,000 & 622,273 & 0,000 & 0 \\
\cline { 2 - 8 } & 2 & 12 & 93,732 & 0,000 & 105,458 & 0,000 & 0 \\
\cline { 2 - 8 } & 3 & 10 & 9,853 & 0,453 & 9,761 & 0,462 & 0 \\
\cline { 2 - 8 } & 4 & 3 & 4,129 & 0,248 & 4,119 & 0,249 & 0 \\
\hline
\end{tabular}

Tablo 1'den de görüleceği gibi, değişkenler arasındaki dörtlü etkileşim etkisi ve üçlü etkileşim etkisi istatistik açıdan anlamlı değildir. Bu durumda, değişkenler arasındaki dörtlü ve üçlü etkileşim etkileri modelde yer almayacaktır.

Değişkenler arasındaki ikili ve üçlü etkileşim etkilerini ve değişkenlerin ana etkilerini test eden kısmi ilişki testi sonuçları da Tablo 2'de verilmiştir:

Tablo 2: Kısmi İlişki Testi Sonuçları

\begin{tabular}{|l|c|c|c|c|}
\hline Etki & Serbestlik derecesi & Kısmi Ki-kare değeri & Anlamlılı seviyesi & İterasyon sayısı \\
\hline K1*K5*K12 & 1 & 1,459 & 0,227 & 4 \\
\hline K1*K5*YK3 & 3 & 0,682 & 0,877 & 3 \\
\hline K1*K12*YK3 & 3 & 6,825 & 0,078 & 3 \\
\hline K5*K12*YK3 & 3 & 0,358 & 0,949 & 3 \\
\hline K1*K5 & 1 & 0,525 & 0,469 & 3 \\
\hline K1*K12 & 1 & 42,076 & 0,000 & 3 \\
\hline K5*K12 & 1 & 37,463 & 0,000 & 3 \\
\hline K1*YK3 & 3 & 1,305 & 0,728 & 4 \\
\hline K5*YK3 & 3 & 1,681 & 0,641 & 4 \\
\hline K12*YK3 & 3 & 1,883 & 0,597 & 4 \\
\hline$K 1$ & 1 & 6,946 & 0,008 & 2 \\
\hline$K 5$ & 1 & 80,259 & 0,000 & 2 \\
\hline K12 & 1 & 76,435 & 0,000 & 2 \\
\hline$Y K 3$ & 3 & 339,420 & 0,000 & 2 \\
\hline
\end{tabular}


Tablo 2'de yer alan kısmi ilişki testi sonuçlarına göre tüm değişkenlerin ana etkileri ve Öğrencinin cinsiyeti* Girişimci olma niyeti ve Öğrencinin kaçıncı çocuk olduğu*Girişimci olma niyeti ikili etkileşim etkileri istatistik açıdan anlamlıdır.

Geriye doğru eleme yöntemiyle belirlenen en uygun model, öğrencinin cinsiyeti, kaçıncı çocuk olduğu, anne babanın girişimci olup olmaması ve öğrencinin girişimcilik niyeti bulunup bulunmaması değişkenlerinin ana etkilerinin ve Öğrencinin cinsiyeti* Girişimci olma niyeti ve Öğrencinin kaçıncı çocuk olduğu*Girişimci olma niyeti ikili etkileşim etkilerinin yer aldığı koşullu bağımsızlık modelidir. Sözü edilen modelin parametre tahminleri Tablo 3'de verilmiştir:

Tablo 3: Koşullu Bağımsızlık Modeli Parametre Tahminleri

\begin{tabular}{|l|c|c|c|c|c|c|}
\hline Parametre & Tahmin & $\begin{array}{c}\text { Standart } \\
\text { hata }\end{array}$ & Z değeri & $\begin{array}{c}\text { Anlamlılı } \\
\text { seviyesi }\end{array}$ & Alt sınır & Üst sınır \\
\hline Sabit & 2,174 & 0,157 & 13,866 & 0,000 & 1,867 & 2,482 \\
\hline K1=1 & 0,546 & 0,090 & 0,055 & 0,000 & 0,369 & 0,723 \\
\hline K5=1 & $-1,022$ & 0,099 & $-10,369$ & 0,000 & $-1,215$ & $-0,829$ \\
\hline K12=1 & $-0,480$ & 0,123 & $-3,919$ & 0,000 & $-0,721$ & $-0,240$ \\
\hline YK3=1 & 1,923 & 0,151 & 12,703 & 0,000 & 1,626 & 2,219 \\
\hline $\mathrm{YK3=2}$ & 1,815 & 0,152 & 11,904 & 0,000 & 1,516 & 2,114 \\
\hline $\mathrm{YK} 3=3$ & 0,806 & 0,170 & 4,743 & 0,000 & 0,473 & 1,140 \\
\hline $\mathrm{K} 5=1^{*} \mathrm{~K} 12=1$ & 0,994 & 0,155 & 6,427 & 0,000 & 0,691 & 1,297 \\
\hline $\mathrm{K} 1=1^{*} \mathrm{~K} 12=1$ & $-1,023$ & 0,152 & $-6,726$ & 0,000 & $-1,321$ & $-0,725$ \\
\hline
\end{tabular}

Tablo 3'te yer alan sonuçlara göre, tüm parametreler istatistik açıdan anlamlıdır. Tabloda yer alan z değerleri, hücre frekanslarını belirlemede hangi değişkenlerin etkisinin daha fazla olduğunu görmemizi sağlar. Buna göre, mutlak değer olarak yüksek z değerleri yüksek etki anlamına gelir. Z değerlerine baktığımızda, öğrencinin ailenin kaçıncı çocuğu olduğu hücre frekanslarını belirlemede en etkili değişkendir. Bu değişkeni, anne ya da babanın girişimci olması, cinsiyet değişkenleri izlemektedir.

Modelin uyum iyiliğini test etmek amacıyla yapılan Ki-kare ve olabilirlik oran testi sonuçları da Tablo 4'te verilmiştir. Test sonuçlarına göre, gözlenen frekanslar ile modelin tahmin ettiği frekanslar arasında anlamlı bir farklılık bulunmadığı anlaşılmaktadır. 
Tablo 4: Modelin Uyum İyiliği Testleri

\begin{tabular}{|l|c|c|c|}
\hline & Ki-kare değeri & Serbestlik derecesi & Anlamlıık seviyesi \\
\hline Olabilirlik oranı & 19,262 & 23 & 0,686 \\
\hline Pearson Ki-kare testi & 19,780 & 23 & 0,655 \\
\hline
\end{tabular}

Uyum iyiliği testlerine göre başarılı olduğu kabul edilen koşullu bağımsızlık modelinin parametreleri aşağıdaki gibi yorumlanacaktır:

Cinsiyet (K1) değişkeni parametre değeri Kadın-1 düzeyi için 0,546 tahmin edilmiştir. Buna göre, odds değeri $=\operatorname{Exp}(0,546)=1,72$ hesaplanmaktadır ve bu değer, tesadüfen seçilecek bir öğrencinin kadın olma olasılığının erkek olma olasılığından yaklaşık 1,72 kat daha fazla olduğunu ifade etmektedir. Cinsiyet değişkeninin Erkek-2 düzeyi için odds değeri, kadın için hesaplanan odds değerinin tersi alınarak kolaylıkla hesaplanabilir. Dolayısıyla, 1/1,72=0,58 değeri bize tesadüfen seçilecek bir öğrencinin erkek olma olasılığının, kadın olma olasılığının 0,58'i kadar olduğunu göstermektedir.

Anne-babanın girişimci olması (K5) değişkeninin parametre tahmini, Evet-1 düzeyi için, $-1,022$ tahmin edilmiştir. Buna göre odds değeri=Exp(-1,022)=0,36 hesaplanmaktadır. Dolayısıyla tesadüfen seçilecek bir öğrencinin girişimci annebabaya sahip olma olasılığı, olmama olasılığının 0,36'sı kadardır. Odds değerinin tersi alınarak, girişimci anne babaya sahip olmama durumu için odds değeri ise, $1 / 0,36=2,78$ hesaplanacaktır. Buna göre, tesadüfen seçilecek bir öğrencinin girişimci anne-babaya sahip olmama olasılığı, olma olasılığına kıyasla 2,78 kat fazla olacaktır.

Öğrencinin mezun olduktan sonra girişimci olma niyeti (K12) değişkeninin Evet-1 düzeyi için parametre tahmini, -0,480'dir. Buna göre odds değeri $=\operatorname{Exp}(-0,480)=0,62$ olmaktadır ve dolayısıyla tesadüfen seçilecek bir öğrencinin mezun olduktan sonra kendi işini kurma niyetinde olması, olmaması olasılığının 0,62'si kadar olacaktır. Odds değerinin tersi alınarak, tesadüfen seçilecek bir öğrencinin girişimcilik niyetinde olmaması olasılığının, olması olasılığından 1/0,62=1,61 kat daha fazla olacağı görülmektedir.

Öğrencinin kaçıncı çocuk olduğu anket formunda açık uçlu soru şeklinde 
sorulmuştur. Daha sonra cevaplar, birinci çocuk-1, ikinci çocuk-2, üçüncü çocuk-3 ve 4. veya daha üst sırada-4 şeklinde kodlanmıştır. Değişkenin kategori sayısının ikiden fazla olması durumunda SPSS paket programı değişkenin son kategorisini referans kategori almakta ve parametre tahminlerini son kategoriye göre gerçekleştirmektedir.

Öğrencinin kaçıncı çocuk olduğu değişkeninin Birinci çocuk-1 kategorisi için parametre 1,923 tahmin edilmiştir. Buna göre odds değeri= $\operatorname{Exp}(1,923)=6,84$ hesaplanmakta ve örneklem içinde birinci çocuk olma olasılığının 4.veya daha sonraki çocuk olmaya kıyasla 6,84 kat fazla olduğu anlaşılmaktadır. Diğer kategoriler için de odds değerleri benzer şekilde hesaplanarak, 4.veya daha üst sırada bir çocuk olmaya kıyasla 2.çocuk olma olasılığının 6,14 kat, 3.çocuk olma olasılığının ise 2,24 kat daha fazla olduğu görülmektedir.

Modelde yer alan öğrencinin anne-babasının girişimci olup olmadığı*öğrencinin girişimci olma niyeti değişkenlerinin etkileşim etkisi1, girişimci anne-babaya sahip olma ve öğrencinin girişimci olmak istediği kategorilerinin çaprazlandığı hücre için parametre tahmini 0,994'dür. Bu durumda ilgili hücrenin odds oranı $\operatorname{Exp}(0,994)=2,70$ hesaplanmaktadır. Dolayısıyla, anne-babası girişimci olan öğrencinin girişimci olma niyeti, anne -babası girişimci olmayana kıyasla 2,70 kat fazladır. Başka bir deyişle anne-babanın girişimci olması öğrencinin girişimci olmasını olumlu yönde etkilemektedir.

Modelde yer alan öğrencinin cinsiyeti*öğrencinin girişimci olma niyeti değişkenlerinin etkileşim etkisi, söz konusu değişkenlerin Kadın ve öğrencinin girişimci olmak istediği kategorilerinin çaprazlandığı hücre için parametre tahmini $-1,023$ 'dür. Bu durumda ilgili hücrenin odds oranı $\operatorname{Exp}(-1,023)=0,36$ hesaplanmaktadır. Dolayısıyla, kadın bir öğrencinin girişimci olma niyeti, erkek öğrencinin girişimci olma niyetinin 0,36'sı kadardır. Dolayısıyla, kadın öğrencilerde girişimcilik niyeti erkek öğrencilere kıyasla önemli ölçüde azdır.

Tablo 5 ise, söz konusu koşullu bağımsızlık modeline göre hesaplanan tahmin

$\left.1{ }^{*}\right)$ işareti söz konusu iki değişkenin etkileşim etkisini ifade etmektedir. 
edilen frekanslar ile gözlenen frekansları göstermektedir. Tabloya göre, standartlaştırılmış kalıntılar (standardized residual) sütunundaki tüm değerler; düzeltilmiş kalıntılar (adjusted residual) sütununda ise iki hücre hariç tüm değerler mutlak değer olarak 2'den küçüktür. Dolayısıyla, model söz konusu iki hücre hariç diğer hücrelerin frekanslarını başarılı şekilde tahmin edebilmektedir.

Tablo 5: Koşullu Bağımsızlık Modeline İlişkin Gözlenen ve Tahmin Edilen Frekanslar

\begin{tabular}{|c|c|c|c|c|c|c|c|c|c|}
\hline Cinsiyet & $\begin{array}{c}\text { Anne- } \\
\text { baba } \\
\text { girişimci } \\
\text { mi? }\end{array}$ & $\begin{array}{l}\text { Girişimcilik } \\
\text { niyeti }\end{array}$ & $\begin{array}{l}\text { Kaçıncı } \\
\text { çocuk }\end{array}$ & $\begin{array}{c}\text { Gözlenen } \\
\text { Frekans }\end{array}$ & $\begin{array}{c}\text { Beklenen } \\
\text { Frekans }\end{array}$ & Kalıntı & $\begin{array}{c}\text { Stand. } \\
\text { kalıntılar }\end{array}$ & $\begin{array}{l}\text { Düzeltilmiş } \\
\text { kalıntılar }\end{array}$ & Sapma \\
\hline \multirow[t]{16}{*}{ Kadın } & \multirow[t]{8}{*}{ Evet } & \multirow{4}{*}{$\begin{array}{l}\text { Kendi işimi } \\
\text { kurmak }\end{array}$} & 1 & 21 & 22,449 & $-1,449$ & $-0,306$ & $-0,373$ & $-0,309$ \\
\hline & & & 2 & 15 & 20,151 & $-5,151$ & $-1,149$ & $-1,372$ & $-1,203$ \\
\hline & & & 3 & 6 & 7,352 & $-1,352$ & $-0,499$ & $-0,541$ & $-0,515$ \\
\hline & & & 4 & 5 & 3,282 & 1,718 & 0,948 & 1,002 & 0,880 \\
\hline & & \multirow{4}{*}{$\begin{array}{l}\text { Bir yerde } \\
\text { ücretli } \\
\text { çalışmak }\end{array}$} & 1 & 38 & 37,387 & 0,613 & 0,100 & 0,126 & 0,100 \\
\hline & & & 2 & 36 & 33,561 & 2,439 & 0,421 & 0,520 & 0,416 \\
\hline & & & 3 & 13 & 12,244 & 0,756 & 0,216 & 0,241 & 0,214 \\
\hline & & & 4 & 3 & 5,466 & $-2,466$ & $-1,055$ & $-1,142$ & $-1,154$ \\
\hline & \multirow[t]{8}{*}{ Hayır } & \multirow{4}{*}{$\begin{array}{l}\text { Kendi işimi } \\
\text { kurmak }\end{array}$} & 1 & 27 & 23,095 & 3,905 & 0,813 & 0,995 & 0,791 \\
\hline & & & 2 & 23 & 20,731 & 2,269 & 0,498 & 0,598 & 0,490 \\
\hline & & & 3 & 4 & 7,563 & $-3,563$ & $-1,296$ & $-1,409$ & $-1,425$ \\
\hline & & & 4 & 7 & 3,376 & 3,624 & 1,972 & 2,086 & 1,720 \\
\hline & & \multirow{4}{*}{$\begin{array}{l}\text { Bir yerde } \\
\text { ücretli } \\
\text { çalışmak }\end{array}$} & 1 & 108 & 103,883 & 4,117 & 0,404 & 0,606 & 0,401 \\
\hline & & & 2 & 90 & 93,252 & $-3,252$ & $-0,337$ & $-0,491$ & $-0,339$ \\
\hline & & & 3 & 34 & 34,020 & $-0,020$ & $-0,003$ & $-0,004$ & $-0,003$ \\
\hline & & & 4 & 13 & 15,188 & $-2,188$ & $-0,561$ & $-0,691$ & $-0,576$ \\
\hline \multirow[t]{16}{*}{ Erkek } & \multirow[t]{8}{*}{ Evet } & \multirow{4}{*}{$\begin{array}{l}\text { Kendi işimi } \\
\text { kurmak }\end{array}$} & 1 & 32 & 36,168 & $-4,168$ & $-0,693$ & $-0,895$ & $-0,707$ \\
\hline & & & 2 & 43 & 32,466 & 10,534 & 1,849 & 2,331 & 1,760 \\
\hline & & & 3 & 14 & 11,844 & 2,156 & 0,626 & 0,701 & 0,609 \\
\hline & & & 4 & 3 & 5,288 & $-2,288$ & $-0,995$ & $-1,078$ & $-1,084$ \\
\hline & & \multirow{4}{*}{$\begin{array}{l}\text { Bir yerde } \\
\text { ücretli } \\
\text { çalışmak }\end{array}$} & 1 & 21 & 21,651 & $-0,651$ & $-0,140$ & $-0,163$ & $-0,141$ \\
\hline & & & 2 & 18 & 19,435 & $-1,435$ & $-0,326$ & $-0,374$ & $-0,330$ \\
\hline & & & 3 & 7 & 7,090 & $-0,090$ & $-0,034$ & $-0,036$ & $-0,034$ \\
\hline & & & 4 & 4 & 3,165 & 0,835 & 0,469 & 0,492 & 0,450 \\
\hline & \multirow[t]{8}{*}{ Hayır } & \multirow{4}{*}{$\begin{array}{l}\text { Kendi işimi } \\
\text { kurmak }\end{array}$} & 1 & 33 & 37,208 & $-4,208$ & $-0,690$ & $-0,894$ & $-0,704$ \\
\hline & & & 2 & 27 & 33,401 & $-6,401$ & $-1,107$ & $-1,401$ & $-1,146$ \\
\hline & & & 3 & 16 & 12,185 & 3,815 & 1,093 & 1,226 & 1,042 \\
\hline & & & 4 & 6 & 5,440 & 0,560 & 0,240 & 0,261 & 0,236 \\
\hline & & \multirow{4}{*}{$\begin{array}{l}\text { Bir yerde } \\
\text { ücretli } \\
\text { çalışmak }\end{array}$} & 1 & 62 & 60,159 & 1,841 & 0,237 & 0,321 & 0,236 \\
\hline & & & 2 & 55 & 54,002 & 0,998 & 0,136 & 0,179 & 0,135 \\
\hline & & & 3 & 18 & 19,701 & $-1,701$ & $-0,383$ & $-0,448$ & $-0,389$ \\
\hline & & & 4 & 9 & 8,795 & 0,205 & 0,069 & 0,078 & 0,069 \\
\hline
\end{tabular}

Çoklu frekans analizine yönelik kurulan ikinci model, Öğrencinin cinsiyeti (K1), 
Öğrencinin ailesinin gelir seviyesi (K11) ve Öğrencinin girişimcilik niyeti (K12) değişkenlerinden oluşmaktadır. Söz konusu modele yönelik değişkenler arasındaki tüm etkileşimler Tablo 6'da gösterilmiştir:

Tablo 6: Değişkenlerin Etkileşim Etkileri

\begin{tabular}{|c|c|c|c|c|c|c|c|}
\hline & & \multicolumn{6}{|c|}{ K-Yönlü ve Yüksek Dereceli Etkiler } \\
\hline & & & \multicolumn{2}{|c|}{ Olabilirlik Oranı } & \multicolumn{2}{|c|}{ Pearson } & \multirow[b]{2}{*}{$\begin{array}{c}\text { İterasyon } \\
\text { Sayısı }\end{array}$} \\
\hline & K & $\begin{array}{c}\text { Serbestlik } \\
\text { derecesi }\end{array}$ & Ki-kare & $\begin{array}{l}\text { Anlamlılık } \\
\text { seviyesi }\end{array}$ & Ki-kare & $\begin{array}{c}\text { Anlamlılık } \\
\text { seviyesi }\end{array}$ & \\
\hline \multirow{3}{*}{$\begin{array}{l}\text { K-yönlü ve } \\
\text { Yüksek Dereceli } \\
\text { Etkiler }\end{array}$} & 1 & 11 & 1015,330 & 0,000 & 1252,482 & 0,000 & 0 \\
\hline & 2 & 7 & 80,602 & 0,000 & 81,401 & 0,000 & 2 \\
\hline & 3 & 2 & 0,253 & 0,881 & 0,252 & 0882 & 4 \\
\hline \multirow[t]{3}{*}{ K-yönlü Etkiler } & 1 & 4 & 934,728 & 0,000 & 1171,081 & 0,000 & 0 \\
\hline & 2 & 5 & 80,348 & 0,000 & 81,149 & 0,000 & 0 \\
\hline & 3 & 2 & 0,253 & 0,881 & 0,252 & 0,882 & 0 \\
\hline
\end{tabular}

Tablo 6'ya göre ikinci etkileşim etkileri istatistik açıdan anlamlı ancak üçlü etkileşim etkisi anlamsızdır. Bu durumda, üçlü etkileşim etkisi modelde yer almayacaktır.

Tablo 7: Kısmi İlişki Testi Sonuçları

\begin{tabular}{|l|c|c|c|c|}
\hline Etki & Serbestlik derecesi & Kısmi Ki-kare değeri & Anlamlılık seviyesi & İterasyon sayısı \\
\hline K1*K12 & 1 & 47,568 & 0,000 & 2 \\
\hline K1*K11 & 2 & 8,468 & 0,014 & 2 \\
\hline$K 12 * K 11$ & 2 & 26,078 & 0,000 & 2 \\
\hline$K 1$ & 1 & 6,946 & 0,008 & 2 \\
\hline$K 12$ & 1 & 76,435 & 0,000 & 2 \\
\hline$K 11$ & 2 & 851,347 & 0,000 & 2 \\
\hline
\end{tabular}

Tablo 7'ye göre, değişkenlere yönelik tüm ana etkiler ve ikili etkileşim etkileri anlamlıdır. Bundan sonraki aşama geriye doğru eleme yöntemiyle uygun modeli belirlemek olacaktır. Üçlü etkileşim parametresi, istatistik açıdan anlamsız olması sebebiyle modelde yer almayacak ve dolayısıyla model, öğrencinin cinsiyeti, ailenin gelir düzeyi ve öğrencinin girişimcilik niyeti değişkenlerinin ana etkileri ile öğrencinin cinsiyeti*öğrencinin girişimci olma niyeti, öğrencinin cinsiyeti*ailenin gelir düzeyi ve ailenin gelir düzeyi*öğrencinin girişimci olma niyeti ikili etkileşim 
etkilerini içeren koşullu bağımsızlık modeli şeklinde kurulacaktır. Sözü edilen modelin parametre tahminleri Tablo 8'de verilmiştir:

Tablo 8: Koşullu Bağımsızlık Modeli Parametre Tahminleri

\begin{tabular}{|l|c|c|c|c|c|c|}
\hline Parametre & Tahmin & $\begin{array}{c}\text { Standart } \\
\text { hata }\end{array}$ & Z değeri & $\begin{array}{c}\text { Anlamlılık } \\
\text { seviyesi }\end{array}$ & Alt sınır & Üst sınır \\
\hline Sabit & 2,644 & 0,215 & 12,318 & 0,000 & 2,223 & 3,065 \\
\hline $\mathrm{K} 1=1$ & 0,755 & 0,225 & 3,358 & 0,001 & 0,314 & 1,195 \\
\hline $\mathrm{K} 12=1$ & 0,880 & 0,225 & 3,914 & 0,000 & 0,439 & 1,321 \\
\hline $\mathrm{K} 11=1$ & 0,114 & 0,318 & 0,359 & 0,719 & $-0,509$ & 0,737 \\
\hline $\mathrm{K} 11=2$ & 2,457 & 0,219 & 11,228 & 0,000 & 2,028 & 2,885 \\
\hline $\mathrm{K} 1=1^{*} \mathrm{~K} 12=1$ & $-1,057$ & 0,156 & $-6,772$ & 0,000 & $-1,363$ & $-0,751$ \\
\hline $\mathrm{K} 1=1^{*} \mathrm{~K} 11=1$ & $-1,095$ & 0,398 & $-2,750$ & 0,006 & $-1,875$ & $-0,315$ \\
\hline $\mathrm{K} 1=1^{*} \mathrm{~K} 11=2$ & $-0,172$ & 0,224 & $-0,770$ & 0,441 & $-0,611$ & 0,266 \\
\hline $\mathrm{K} 12=1^{*} \mathrm{~K} 11=1$ & $-1,220$ & 0,399 & $-3,062$ & 0,002 & $-2,001$ & $-0,439$ \\
\hline $\mathrm{K} 12=1^{*} \mathrm{~K} 11=2$ & $-1,122$ & 0,224 & $-5,013$ & 0,000 & $-1,561$ & $-0,683$ \\
\hline
\end{tabular}

Tablo 9'da ise modelin uyum iyiliği testlerine yönelik test istatistikleri görülmektedir. Buna göre, gözlenen ve tahmin edilen frekanslar arasında istatistik açıdan anlamlı bir fark bulunmadığı ve modelin gözlenen frekansları başarılı bir şekilde tahmin ettiği kabul edilecektir.

Tablo 9: Modelin Uyum İyiliği Test İstatistikleri

\begin{tabular}{|l|c|c|c|}
\hline & Ki-kare değeri & Serbestlik derecesi & Anlamlılı seviyesi \\
\hline Olabilirlik oranı & 0,253 & 2 & 0,881 \\
\hline Pearson Ki-kare testi & 0,252 & 2 & 0,882 \\
\hline
\end{tabular}

Tablo 8'de yer alan parametre tahminlerine göre, hücre frekanslarını belirlemeye yönelik tüm parametreler istatistik açıdan anlamlıdır. Z değerlerine baktığımızda ise, hücre frekanslarını tahmin etmede en büyük etkinin ailenin gelir düzeyi değişkeninde $(11,228)$ olduğunu görüyoruz.

Modelin değişkenlere yönelik ana etki parametrelerinin üstel değerleri hesaplanarak odds değerleri kolaylıkla hesaplanır. Buna göre, Kadın-1 odds değeri $\operatorname{Exp}(0,755)=2,13$, öğrencinin girişimcilik niyeti- 1 odds değeri $\operatorname{Exp}(0,880)=2,41$, Ailenin gelir düzeyi-2 odds değeri, $\operatorname{Exp}(2,457)=11,67$ hesaplanmaktadır. Söz 
konusu odds değerleri ilk modelde olduğu gibi yorumlanacaktır.

Modelde tahmin edilen ikili etkileşim parametrelerinden hareketle odds oranları da hesaplanabilir. Öğrencinin cinsiyeti Kadın- $1 *$ Öğrencinin girişimcilik niyeti-1 hücresi için odds oranı $\operatorname{Exp}(-1,057)=0,35^{\prime}$ dir. Bu durumda, kadın öğrencilerin girişimcilik eğilimi erkek öğrencilere kıyasla daha azdır ve dolayısıyla cinsiyet girişimcilik niyeti üzerinde etkili bir faktördür.

Ailenin gelir düzeyi-1*Öğrencinin girişimcilik niyeti-1 hücresi için ikili etkileşim parametresi, $-1,220$ tahmin edilmiştir. Buna göre odds oranı $\operatorname{Exp}(-1,220)=0,30$ olarak hesaplanmaktadır. Benzer şekilde Ailenin gelir düzeyi-2*Öğrencinin girişimcilik niyeti-1 hücresi ikili etkileşim parametresi $-1,122$ ve odds oranı da $\operatorname{Exp}(-1,122)=0,33$ hesaplanmaktadır. Buna göre, öğrencinin girişimcilik eğilimi üzerinde ailesinin gelir düzeyinin etkili bir faktör olduğu ve düşük veya orta gelir düzeyinde bir aileye mensup öğrencilerin girişimcilik eğiliminin, yüksek gelir düzeyinde bir aileye sahip olan öğrencilere kıyasla daha düşük olduğu anlaşılmaktadır.

\section{Sonuç}

Girişimci, üretim faktörlerini bir araya getirerek üretim yapan ve dolayısıyla katma değer ve istihdam yaratan önemli bir ekonomik unsurdur. Bu sebeple girişimcilik ekonomik büyüme ve kalkınma açısından da önemli bir araçtır. Ekonomik açıdan dışsal fayda sağlayan girişimci ve girişimcilik kavramları son yıllarda çokça konuşulur ve tartışılır olmuştur.

Girişimciliği belirleyen faktörlerin neler olduğuna yönelik çalışmalar da konunun günden güne daha çok önemsenmesiyle birlikte artmıştır. Bireylerin kişilik özellikleri yanında bireyin demografik özelliklerinin de girişimcilik eğilimi üzerinde etkili olduğu düşünülmekte ve bu anlamda ailenin eğitim düzeyi, ailede girişimci ebeveyn bulunup bulunmadığı, bireyin yaşı, cinsiyeti, ilk çocuk olup olmadığı ve ailenin sosyoekonomik yapısı, girişimcilik eğilimini belirleyen faktörler olarak değerlendirilmektedir. Ayrıca, ailenin ve bireyin kırsal ya da kentsel alanda 
yaşıyor olması da girişimcilik eğilimi üzerinde etkili bir diğer faktör kabul edilmektedir.

Öğrencilerin Demografik Özelliklerinin Girişimcilik Eğilimi Üzerindeki Etkilerinin Çok Yönlü Frekans Analiziyle Belirlenmesi isimli bu çalışma ile, İstanbul Üniversitesi İktisat Fakültesi öğrencilerinin girişimcilik niyetlerinin aile ve demografik özellikleriyle ilişkisini belirlemek amaçlanmıştır. Sözü edilen amaç doğrultusunda İktisat Fakültesinin lisans diploma programlarına kayıtlı örgün eğitim gören 883 öğrenciyle görüşülmüş ve gönüllülük esasına göre kağıt-kalem kullanılarak gerçekleştirilen yüz yüze görüşmeler ile veri toplama işlemi gerçekleştirilmiştir.

Girişimcilik eğilimini belirlemek üzere öğrencilere, mezun olduktan sonra ücretli çalışma ya da kendi işini kurma seçeneklerinden uygun olanı seçmeleri istenmiş ve girişimcilik niyetleri verdikleri cevaba göre belirlenmiştir.

Demografik özellikler ile aile özelliklerini gösterir değişkenler açısından kayıp gözlemler içeren anketler elenerek 811 anket verisi ile çok yönlü frekans analizi çözümlemesi yapılmışır. Uygun modeller olarak belirlenen logaritmik doğrusal modellerin sonuçlarına göre cinsiyetin, anne-babanın girişimci olmasının, ailenin gelir seviyesinin ve kaçıncı çocuk olarak dünyaya gelindiğinin girişimcilik eğilimi üzerinde etkili olduğu anlaşılmıştır. Buna göre, erkek öğrencilerde kendi işini kurma tercihi kadın öğrencilerden fazladır. Anne-babası girişimci olan öğrencilerde girişimcilik eğilimi daha yüksektir. Öte yandan öğrencilerin yüksek gelirli aile mensubu olmaları durumunda daha girişimci niyette oldukları ortaya çıkmaktadır. İlk veya ikinci çocuk olan öğrencilerde girişimcilik niyetinin diğer çocuklara kıyasla daha fazla olduğu tespit edilmiştir.

Devlet ve vakıf üniversitelerinde öğrenim gören öğrencilerin girişimcilik eğilimlerinin farklıık gösterip göstermediği ya da farklı fakülte öğrencileri arasında girişimcilik eğilimi açısından fark olup olmadığı bundan sonra yapılacak çalışmalarla araştırılabilir. Öte yandan, özellikle girişimcilerin kişilik özellikleri dikkate alınarak anaokulları düzeyinde öğrencilerin kişilik özelliklerinin bu yönde gelişimine 
yönelik neler yapılabileceği belirlenmeli ve okul öncesi eğitim buna göre planlanmalıdır.

Sonuç olarak, bireylerin girişimci olma niyetleri üzerinde aile ve demografik özellikler önemli ölçüde etkili faktörlerdir. Söz konusu faktörler insanın içine doğduğu koşulları ve cinsiyet gibi doğuştan getirdiği özellikleri ifade ettiğinden bu faktörlerin girişimciliği arttırmak amacıyla bir politika aracı olarak kullanılması güçtür. Dolayısıyla, girişimcilik eğilimini arttırmak ancak sonradan kazanılabilecek özellikler ile mümkün olabilir. Bu açıdan, girişimcilik eğilimi yüksek bireylerin yetişmesi, ancak eğitim ile sağlanabilir. Bunun için, girişimci bireylerde görülen özelliklerin, anaokullarından başlayarak küçük yaşlardan itibaren çocuklara benimsetilmesi yoluna gidilebilir. Ayrıca, girişimcilik eğilimi üzerinde çevre faktörü olarak nitelendirilen, hükümet politikaları, ekonomik ve finansal altyapı, yasal düzenlemeler vb. koşulların girişimciliği teşvik edici hale getirilmesi önerilebilir.

Hakem Değerlendirmesi: D1ş bağımsız.

Çıkar Çatışması: Yazar çıkar çatışması bildirmemiştir.

Finansal Destek: Yazar bu çalışma için finansal destek almadığını beyan etmiştir.

Peer-review: Externally peer-reviewed.

Conflict of Interest: The author has no conflict of interest to declare.

Grant Support: The author declared that this study has received no financial support.

\section{Kaynaklar/References}

Altaş, D. ve Yıldırım, E. (2003). "Lisansüstü Eğitime Giriş Sınavı (LES) Sonuçlarının Üç Yönlü Çapraz Sınıflandırma Tablosu ile İncelenmesi", Marmara Üniversitesi Sosyal Bilimler Enstitüsü Öneri Dergisi, 5(20), 213-223.

Agresti, A. (2007). An Introduction to Categorical Data Analysis, Second Edition, John Wiley \& Sons, New Jersey.

Arslan, K. (2002). "Üniversiteli Gençlerde Mesleki Tercihler ve Girişimcilik Eğilimleri, Doğuş Üniversitesi Dergisi, 6, 1-11.

Azen, R. ve Walker, C. M. (2011). Categorical Data Analysis for the Behavioral and Social Sciences, Routledge Taylor \& Francis Group, New York.

Ballı, E. ve Ballı, A. İ. K. (2014). Üniversite Öğrencilerinin Bireysel Değerleri ve Girişimcilik Eğilimleri, Çukurova Üniversitesi IiBF Dergisi, 18(1), 101-121.

Börü, D. (2006). Girişimcilik Eğilimi Marmara Üniversitesi İşletme Bölümü Öğrencileri Üzerine Bir 
Araştırma, Marmara Üniversitesi Yayını Yayın No:733, İstanbul.

Çelik, A., İnce, M., Bozyiğit, S. (2014). "Üniversite Öğrencilerinin Girişimcilik Niyetlerini Etkileyen Ailesel Faktörleri Belirlemeye Yönelik Bir Çalışma", Niğde Üniversitesi İktisadi ve İdari Bilimler Fakültesi Dergisi, 7(3), 113-124.

Durak, İ. (2011). "Girişimciliği Etkileyen Çevresel Faktörlerle Illgili Girişimcilerin Tutumları: Bir Alan Araştırması", Yönetim Bilimleri Dergisi, 9(2), 191-213, Çevrimiçi: https://dergipark.org.tr/tr/ download/article-file/705502, 25.02.2021.

Duygulu, E. (2008). "Algılanan Kurumsal Görünüm, Proaktif Kişilik Özelliği ve İş Kurma (Girişimcilik)

Tutumu: Dokuz Eylül Üniversitesi Sosyal Bilimler Enstitüsü Öğrencileri Üzerine Bir İnceleme, Dokuz Eylül Üniversitesi Sosyal Bilimler Enstitüsü Dergisi, 10(2), 95-120.

İbicioğlu, H., Özdaşlı, K., Alparslan, A.M. (2009). "Girişimci Özellikler ve Girişimcilik Türü Tercihi Üzerinde Ebeveyn Etkisi: Mehmet Akif Ersoy Üniversitesi Araştırması", Selçuk Üniversitesi MYO Dergisi, 12(1-2), 521-538.

İrmiş, A. ve Barutçu, E. (2012). "Öğrencilerin Kendilerini Girişimci Bir Kişiliğg Sahip Görmelerini ve İş Kurma Niyetlerini Etkileyen Faktörler: Bir Alan Araştırması", Atatürk Üniversitesi İktisadi ve İdari Bilimler Dergisi, 26(2), 1-25.

Kalkan, A. (2011). "Kişisel Tutum, Öznel Norm ve Algılanan Davranış Kontrolünün Girişimcilik Niyeti Üzerindeki Etkisi: Üniversite Öğrencileri Üzerine Bir Uygulama", Süleyman Demirel Üniversitesi Sosyal Bilimler Enstitüsü Dergisi, S.14. ss. 189-206.

Karagül, M., (2013). "Kalkınma Sürecinde Üretim Faktörlerinin Yeniden Tanımlanması", Leges Ekonomi ve Hukuk Araştırmaları Dergisi, 1(1), ss.1-11.

Kaygın, E., Güven, B., (2015). Girişimcilik: Temel Kavramlar, Girişimcilik Türleri, Girişimcilikte Güncel Konular, Siyahinci Akademi Yayınlar, Çevrimiçi: https://www.researchgate.net/ publication/329104760_GIRISIMCI_OLMAYI_BELIRLEYEN_FAKTORLER, 23.03.2021.

Korkmaz, O. (2012). "Üniversite Öğrencilerinin Girişimcilik Eğilimlerini Belirlemeye Yönelik Bir Araştırma: Bülent Ecevit Üniversitesi Örneği", Afyon Kocatepe Üniversitesi IIIBF Dergisi 14(2), 209-226.

Kök, S. B. (2007). Küçük ve Orta Ölçekli İşletmeler ve Kadın Girişimciliği, Denizli Ticaret Odası Ekonomik Araştırma Serisi Yayın No:1.

Lee, S. M., Lim, S., Pathak, R. D., Chang, D. ve Li, W. (2011). "Culture and Entrepreneurial Orientation: A Multi-Country Study", International Entrepreneurship Management Journal, 7, 1-15.

Littunen, H. (2000). "Entrepreneurship and the Characteristics of the Enrepreneurial Personality", International Journal of Entrepreneurial Behavior \&Research, 6(6), 295-309.

Mueller, S. L. ve Anisya S. T. (2000). "Culture and Entrepreneurial Potential: A NineCountry Study of Locus of Control and Innovativeness", Journal of Business Venturing, 16, 51-75.

Örücü, E., Kılıç, R., Yılmaz, Ö. (2007). "Üniversite Öğrencilerinin Girişimcilik Eğilimlerinde Ailesel Faktörlerin Etkisi Üzerine Bir Uygulama", Çanakkale 18 Mart Üniversitesi Girişimcilik ve Kalkınma Dergisi, 2(2) 27-47.

Saraçbaşı, T. ve Altunay, S. A. (2016). Kategorik Veri Çözümlemesi, Hacettepe Üniversitesi Yayınları, 
Ankara.

Şeşen, H. ve Basım, H. N. (2012). "Demografik Faktörler ve Kişiliğin Girişimcilik Niyetine Etkisi: Spor Bilimleri Alanında Eğitim Gören Üniversite Öğrencileri Üzerine Bir Araştırma", Ege akademik Bakış, 12(Özel Sayı), 21-28.

Teoh, H. Y. ve Foo, S. L. (1997). "Perceived Performance Relationship: Evidence From Singaporean Entrepreneurs", Journal of Business Venturing, 12, 67-81.

Topaloğlu, E. ve Atay, A. (2020). "Kategorik Verilerin Analizinde Logaritmik Doğrusal Modellerin Kullanımı: İntihar Olasılığı Verileri Üzerine Bir Uygulama", Optimum Ekonomi ve Yönetim Bilimleri Dergisi, 7(2), 565-580.

Türker, D. ve Senem S. S. (2009). "Which Factors Affect Entrepreneurial Intention of University Students?", Journal of European Industrial Training, Vol. 33(2), 142-159.

Ulutürk, A. S. ve Bektaş, H. (2015). "Üniversite Öğrencilerinin Girişimci Özelliklerinin İncelenmesi" Marmara Üniversitesi I.I.B. Dergisi, 37(1), 309-318. 
